\title{
AMMONIA EMISSIONS FROM CATTLE MANURE VERSUS ITS QUANTITY
}

\author{
Vladislav Gordeev, Tatiana Mironova, Evgenia Lantsova \\ Institute for Engineering and Environmental Problems in Agricultural Production, Russia \\ cow-sznii@yandex.ru
}

\begin{abstract}
The indoor climate in livestock houses is one of the significant factors affecting the productivity of animals. To create an optimal inside environment the proper inside-outside air exchange is required. This leads to significant emissions of harmful substances generated in the rooms: ammonia, methane, carbon dioxide, etc. Manure removal systems account for $27 \%$ of the general negative impact on the environment of livestock technologies. The factors influencing the release of ammonia from cattle manure were studied in laboratory setting. Two most significant and linearly independent factors were identified: the area of the polluted surface and the thickness of the manure layer. For research purposes, a laboratory installation was designed, consisting of a body with a fan and an exhaust pipe with an ammonia concentration sensor and air velocity transmitter. Manure with relative moisture content of $W=87.3 \%$ was placed in the body of the installation; the air was blown over the manure surface by the fan and the sensors in the pipe recorded the ammonia concentration and the air flow rate. The ammonia emission from manure was calculated. The obtained data indicated that the area of the manure surface had the greatest impact on the ammonia emission, and with its increase, the emission grew. Analysis of the mean values revealed that the biggest ammonia emission of $129.56 \mathrm{mg} \cdot \mathrm{h}^{-1}$ from the manure was in the variant with the maximum surface area and thickness of the manure layer.
\end{abstract}

Keywords: ammonia emission, inside climate, manure, cow barn.

\section{Introduction}

The indoor climate in livestock houses is one of the significant factors affecting the productivity of animals.To create an optimal inside environment the harmful substances from livestock houses are to be removed through the air exchange with the outside air. At the same time, the ventilation air continuously releases into the atmosphere the harmful substances generated inside: ammonia, methane, carbon dioxide, etc. [1-4]. Barn construction, air temperature and ventilation, composition of the ration of feeding, bedding, frequency of manure removing have a significant effect on ammonia emissions from dairy farms [5-7]. Analysis of agricultural production processes showed that $27 \%$ of the total negative impact of a livestock enterprise account for the manure removal system [8]. Reduction of ammonia emissions is possible by lowering the temperature in the barn, by reducing the speed of the air movement above the surface of ammonia emissions [9], by reducing the surface area soiled with manure [10], while the effect of manure amount accumulated on the barn floor is underinvestigated.

The effect of manure quantity (manure polluted area and manure layer thickness) on ammonia emissions was estimated in laboratory-scale investigations with the aim to improve the inside environment in animal housing facilities.

\section{Materials and methods}

Statistical methods of experiment planning were applied. Two most significant and linearly independent factors were identified: the manure polluted surface area and the thickness of the manure layer (Table 1). One more factor - moisture content of manure was the same in all experiments $87.3 \%$.

Table 1

Levels of factors and variation intervals

\begin{tabular}{|c|c|c|c|c|c|}
\hline \multirow{2}{*}{ Factors } & \multirow{2}{*}{ Symbol } & \multirow{2}{*}{$\begin{array}{c}\text { Variation } \\
\text { interval }\end{array}$} & \multicolumn{3}{|c|}{ Variation levels } \\
\hline & & & -1 & $\mathbf{0}$ & +1 \\
\hline Area covered by manure, $\mathrm{m}^{2}$ & $X_{1}$ & 0.030 & 0.030 & 0.060 & 0.090 \\
\hline Manure layer thickness, $\mathrm{m}$ & $X_{2}$ & 0.015 & 0.015 & 0.03 & 0.045 \\
\hline
\end{tabular}

For research purposes, a laboratory installation was designed, consisting of a body and an exhaust pipe (Fig. 1). The body was a chamber with the volume of $0.089 \mathrm{~m}^{3}$ with a fan, opposite to which the pipe was attached with an ammonia concentration sensor (Astra-D) and an air velocity transmitter EE65-VCK 500 inside. The data were stored on the computer via "Paragraph" electronic recorder. 
Analysed material (manure) was put in a tray with the corresponding area and height according to the experiment design and placed in the installation chamber.

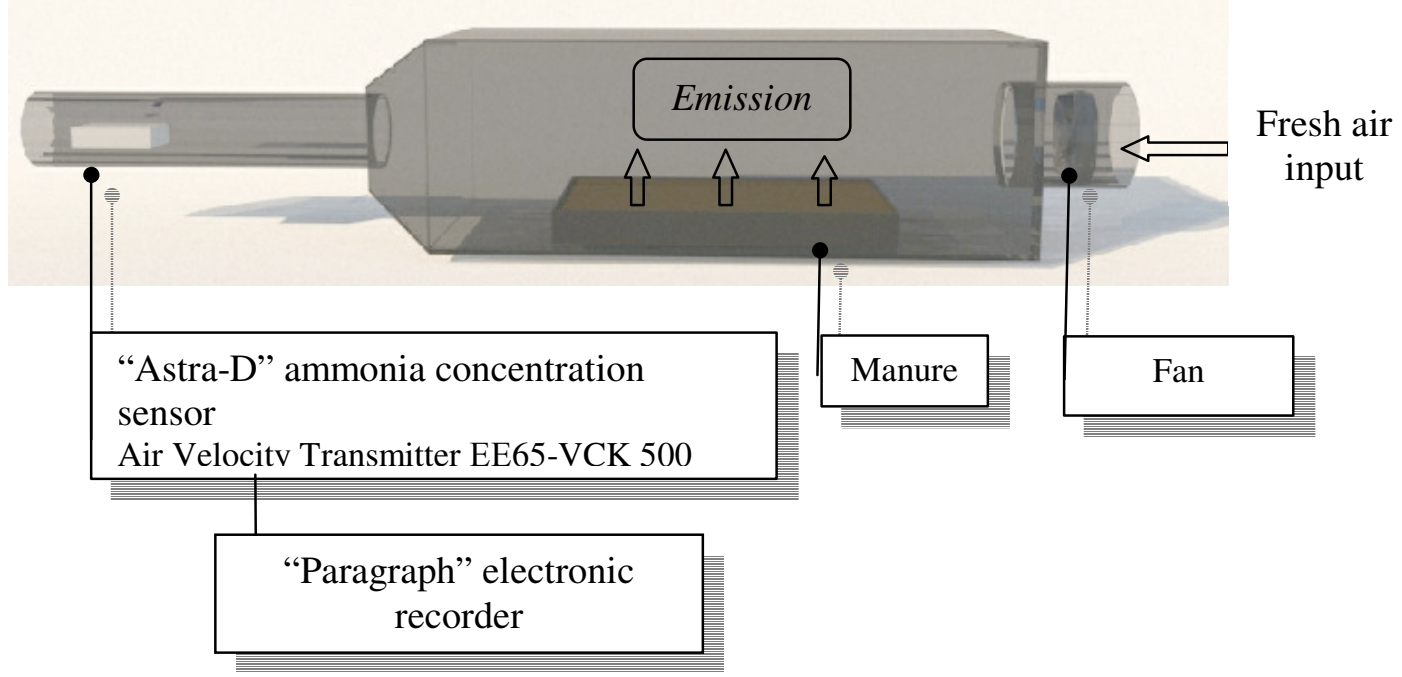

Fig. 1. Model of laboratory-scale installation to study ammonia emission from cattle manure

The samples of manure for the analysis were taken in one of the agricultural enterprises in Leningrad Region with standard cow barns with loose cubicle housing of cows without bedding on rubber mats. The samples were taken in special airtight containers from the manure canal in five spots in the barn. Before the measurements the samples were thoroughly mixed with each other.

To create reliable mathematical models, a randomized matrix was used in the experiments, which was generated using STATGRAPHICS Plus.

Manure with the relative moisture content $W=87.3 \%$ was placed in the body of the installation; the air was blown over the manure surface by the fan and the sensors in the pipe registered the ammonia concentration and air velocity. Each experiment variant lasted for 30 minutes. The ammonia concentrations were recorded each 15 seconds.

The results were processed by well-known methods of mathematical statistics, with the average values for the established time periods being determined. The ammonia emission from manure was calculated from the obtained data [11]:

$$
G=q_{N H 3} \cdot L
$$

where $\quad G$-ammonia emission, $\mathrm{mg} \cdot \mathrm{h}^{-1}$;

$q_{N H 3}$ - average concentration of ammonia, $\mathrm{mg} \cdot \mathrm{m}^{-3}$;

$L$ - ventilated air flow rate in the installation pipe, $\mathrm{m}^{3} \cdot \mathrm{h}^{-1}$

Air flow rate in the installation pipe was calculated by the formula (2) [11]:

$$
L=3600 \cdot F \cdot V_{B} ;
$$

where $L-$ air flow rate in the installation pipe, $\mathrm{m}^{3} \cdot \mathrm{h}^{-1}$;

$F$ - cross-section area of the exhaust pipe, $\mathrm{m}^{2}$;

$V_{6}$ - air velocity in the pipe, $\mathrm{m} \cdot \mathrm{s}^{-1}$.

Ammonia emission from the manure was calculated for each ammonia concentration value. After that the data were averaged for each experiment variant. As a result, mathematical dependences of the influence of the manure layer thickness and the area of polluted surface on ammonia emissions were obtained.

\section{Results and discussion}

During the experiments, the smallest value of ammonia concentration was $0.608 \mathrm{mg} \cdot \mathrm{m}^{-3}$, the biggest one $-3.014 \mathrm{mg} \cdot \mathrm{m}^{-3}$. The maximum values were recorded in the variant with the highest values of the factors under investigation. 
Calculated values of ammonia emissions from manure are presented in Table 2.

Experiment findings

Table 2

\begin{tabular}{|c|c|c|c|}
\hline \multirow[b]{2}{*}{$\begin{array}{l}\text { Number of } \\
\text { experiment }\end{array}$} & \multicolumn{2}{|c|}{ Coded factors } & \multirow{2}{*}{$\begin{array}{c}\text { Ammonia } \\
\text { emission } \\
G, \mathbf{m g}^{-1}\end{array}$} \\
\hline & $\begin{array}{l}\text { Area polluted with manure } \\
\qquad X_{1}\end{array}$ & $\begin{array}{c}\text { Manure layer thickness } \\
\qquad \mathrm{X}_{2}\end{array}$ & \\
\hline 1 & 0 & +1 & 69.00 \\
\hline 2 & +1 & 0 & 110.78 \\
\hline 3 & 0 & 0 & 85.54 \\
\hline 4 & -1 & -1 & 39.62 \\
\hline 5 & -1 & 0 & 35.88 \\
\hline 6 & +1 & +1 & 129.56 \\
\hline 7 & -1 & +1 & 46.28 \\
\hline 8 & +1 & -1 & 116.00 \\
\hline 9 & 0 & -1 & 84.37 \\
\hline
\end{tabular}

Multiple regression analysis of the effect of the factors under investigation on ammonia emission from manure resulted in a mathematical model in the coded form:

$$
\begin{gathered}
G=77.3667+39.0933 \cdot X_{1}+0.808333 \cdot X_{2}+0.05 \cdot X_{1}^{2}+1.725 \cdot X_{1} \cdot X_{2}+3.405 \cdot X_{2}^{2} ; \\
R^{2}=0.9609 ;
\end{gathered}
$$

where $G$-ammonia emission, $\mathrm{mg} \cdot \mathrm{h}^{-1}$;

$X_{1}$ - coded value of area polluted with manure, $\mathrm{m}^{2}$;

$X_{2}$ - coded value of thickness of manure layer, $\mathrm{m}$;

$R^{2}$ - coefficient of determination.

The obtained equation of regression was used to plot three-dimensional response surface and the contours of its cross-sections (Fig. 2).
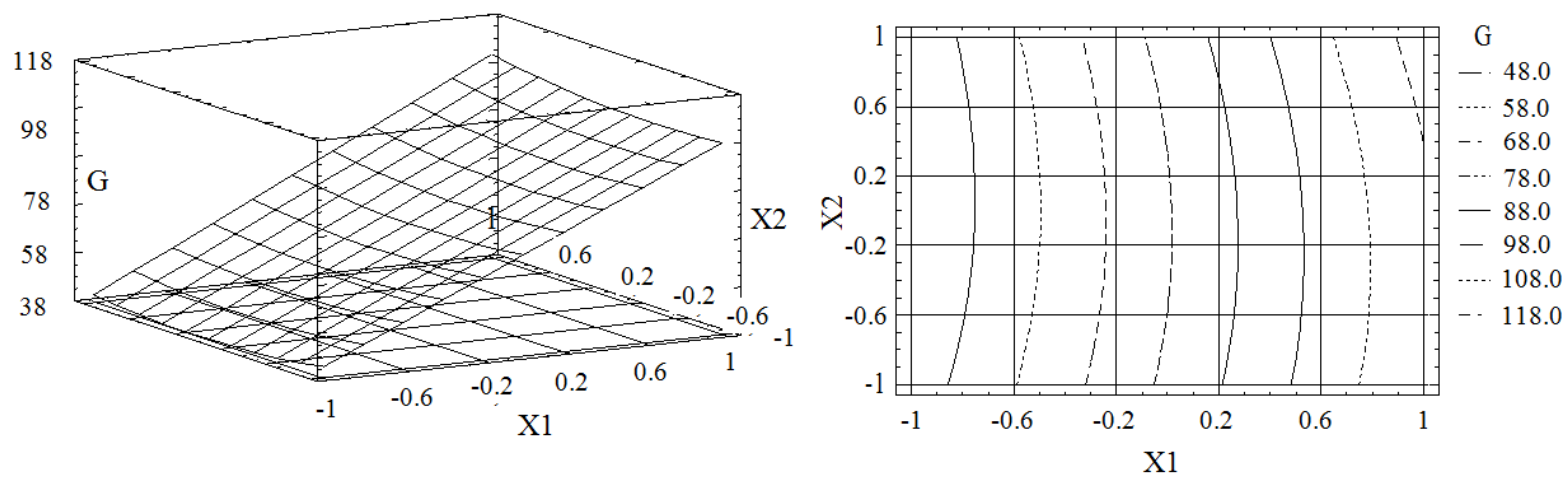

Fig. 2. Response surface and contour of its cross-section showing effect of surface area and layer thickness on ammonia emission from manure

The resulting data indicated that the highest average ammonia emission from manure was obtained in the variant with the maximum area and thickness of manure layer and amounted to $129.56 \mathrm{mg} \cdot \mathrm{h}^{-1}$, that was 3.6 times higher than in the variant with the lowest value.

Threefold increase in the area under study resulted in 2.9 times bigger mean value of ammonia emission. When the thickness changed by $15 \mathrm{~mm}$, the emission varied only up to $5.5 \%$.

\section{Conclusions}

The study found that ammonia emission is most affected by the surface area of manure and with its increase, the emission also increased. Manure layer thickness below $4.5 \mathrm{~cm}$ did not have a significant effect on ammonia emission. Since it is impossible to reduce the area of manure passages for lower ammonia emissions in the case of loose cubicle housing of cows, further research is needed 
to identify the factors that contribute to lower the ammonia emissions from manure in the barn, for example, humidity and temperature.

\section{References}

[1] Casey K.D., Bicudo J.R., Schmidt D.R., Singh A., Gay S.W., Gates R.S., Jacobson L.D., Hoff S.J. Air quality and emissions from livestock and poultry production/waste management systems. Animal Agriculture and the Environment. National Center for Manure and Animal Waste Management White Papers. ASABE, St. Joseph, Michigan, 2006, pp. 1-40.

[2] Gordeev V., Mironov V. Use of ventilation emissions from animal barn for improvement of plant growth. Proceedings 13th International Scientific Conference "Engineering for Rural Development", May 29-30, 2014, Jelgava, pp. 99-102.

[3] Vtoryi V., Vtoryi S., Gordeev V., Lantsova E. Carbon dioxide emission from cattle manure removed by scrapers. Proceedings 16th International Scientific Conference "Engineering for Rural Development”, May 24-26, 2017, Jelgava, pp. 590-593.

[4] Kochish I.I., Kalyuzhniy N.S., Voltchkova L.A., Nesterov V.V. Zoohygiene: Textbook. (Ed. I.I. Kochish). Lan' Publishers, Saint-Petersburg, 2008, 464 p. - ISSN 978-5-8114-0773-6. (In Russian)

[5] Hristov A.N., Hanigan M., Cole A., Todd R., McAllister T.A., Ndegwa P.M., Rotz A. Review: Ammonia emissions from dairy farms and beef feedlots1. Canadian Journal of Animal Science. 91 (1), 2011, pp. 1-35.

[6] Hristov A.N. (2013). Diet formulation as an effective tool for mitigating nitrogen excretion in dairy systems. Advances in Animal Biosciences. 4.

[7] Misselbrook T. H., Webb J., Gilhespy S. L. Ammonia emissions from outdoor concrete yards used by livestock quantification and mitigation. Atmos. Environ. 40, 2006, pp. 6752-6763.

[8] Субботин И.А.; Васильев Э.В., Усовершенствованная методика оценки эффективности наилучших доступных технологий для интенсивного животноводства (Advanced method for assessment of Best Available Techniques for intensive livestock farming). Технологии и технические средства механизированного производства продукции растениеводства и животноводства (Technologies, machines and equipment for mechanised crop and livestock production). 2016. No 88. pp. 142-152. (In Russian)

[9] Bleizgys R., Bagdoniene I. Control of ammonia air pollution through the management of thermal processes in cowsheds. Science of The Total Environment. 2016, 568 p.

[10] Groenestein C.M., Valli L., Piñeiro Noguera C., Menzi H., Bonazzi G., Döhler H., Van der Hoek K., Aarnink A.J.A., Oenema O., Kozlova N., Kuczynski T., Klimont Z., Montalvo Bermejo G. Livestock housing. Options for Ammonia Mitigation Guidance from the UNECE Task Force on Reactive Nitrogen. Edinburgh. 2014. pp. 14-25.

[11]Брюханов А.Ю., Козлова Н.П., Максимов Н.В. Способ определения и мониторинга величины массовых выбросов загрязняющих веществ в окружающую среду из животноводческого помещения и система его осуществления (Method to determine and monitor the amount of mass emissions of pollutants into the environment from livestock premises and the system for its implementation). Patent RF No. 2477886. 2013. (In Russian) 